\title{
Hubungan Bisnis dan Supply Chain Information antara Disperinaker dan Industri Kecil Menengah
}

\author{
Dio Febrilian Tanjung*, Aulia Oktaviana, Gilang Muhamad Noer, Suci Larasati, \\ Zati Hulwani, Eko Sediyono, Aris Puji Widodo \\ Sistem Informasi, Sekolah Pasca Sarjana, Universitas Diponegoro, \\ Jl. Imam Bardjo SH No.5, Pleburan, Kec. Semarang Selatan, Kota Semarang, Jawa Tengah 50241 \\ *e-mail: diofebrilian@gmail.com
}

(received: 22 November 2020, revised: 23 November 2020, accepted: 22 Desember 2020)

\begin{abstract}
Abstrak
IKM sebagai salah satu penyumbang ekonomi daerah, dirasa penting untuk mempertahankan dan meningkatkan IKM tersebut. Pemerintah melalui Disperinaker memiliki fungsi dalam membantu IKM untuk bertahan dan meningkatkan keterampilan, agar IKM mampu bersaing dengan usaha besar lainnya. Hubungan yang terjadi antara IKM dan Disperinaker dapat dikatakan sebagai hubungan bisnis karena terjadi pertukaran informasi serta kerja sama yang saling menguntungkan antara kedua belah pihak. Hubungan bisnis ini bisa saja dipengaruhi oleh beberapa faktor. Penelitian ini mengukur seberapa besar pengaruh faktor sosial, budaya, teknologi, waktu dan geografis terhadap hubungan bisnis antara IKM dan Disperinaker. Supply Chain Information yang terjadi antara Disperinaker dan IKM juga ditelusuri pada penelitian ini, menjelaskan bagaimana arus informasi yang beredar antar kedua mitra ini. Mengetahui arus informasi antar kedua mitra ini dapat memberikan gambaran terkait pengembangan lebih lanjut baik pemanfaatan teknologi pada proses supply chain information tersebut. Metode yang digunakan adalah mixed methods dengan tipe desain convergent parallel. Dengan menggunakan regresi linear berganda, menunjukkan bahwa variabel teknologi memiliki pengaruh berarti. Selain itu supply chain information yang terjadi antara Disperinaker dan IKM yaitu pengadaan pelatihan, menampilkan produk di ruang pameran dan mengikuti kegiatan pameran yang diadakan oleh Disperinaker.
\end{abstract}

Kata Kunci: hubungan bisnis, supply chain management, supply chain information, teknologi informasi

\section{Abstract}

IKM is considered important to maintain and increase itselves as one of the contributors to the regional economy. The goverment through Disperinaker has a function in helping IKM to survive and improve skills, so that IKM can compete with other big businesses. The relationship occured between IKM and Disperinaker can be said to be a business relationship because there is an exchange of information and mutually beneficial cooperation between two parties. This business relationship may be influenced by several factors. This study measures how much influence social, cultural, technological, time and geographical factors have on the business relationship between IKM and Disperinaker. Supply Chain Information occured between Disperinaker and IKM is also traced to explain how the flow of information circulating between these two partners. Knowing the flow of information between them can provide an overview regarding the further development of better technology utilization in the supply chain information process. The method used is mixed methods with parallel convergent design type. By using multiple linear regression, it shows that the technology variable has a significant effect. In addition, the supply chain information occured between Disperinaker and IKM is the provision of training, displaiying products in the exhibition hall and participating in exhibition activities held by the Disperinaker.

Keywords: business relationships, supply chain management, supply chain information, technology information 


\section{Pendahuluan}

Pada era desentralisasi saat ini, pemerintah daerah berupaya untuk mendirikan Industri Kecil Menengah (IKM) di daerahnya sebagai usaha untuk mendorong pembangunan ekonomi daerah. Pertumbuhan IKM di daerah berkaitan dengan otonomi daerah yang memberikan kemampuan kepada daerah untuk mengatur daerahnya sendiri. Pemerintah suatu daerah mengelola pemanfaatan sumber daya berdasarkan potensi lokal, termasuk dalam hal mengendalikan suatu IKM di daerah. Masyarakat kecil menjadi dasar operasional IKM pada masing-masing daerah. IKM juga merupakan salah satu dasar penunjang perekonomian nasional, sehingga pemerintah daerah perlu lebih memperhatikan pertumbuhan IKM.

Dinas Perindustrian dan Tenaga Kerja (Disperinaker) memiliki fungsi dalam melaksanakan urusan pemerintah di bidang perindustrian yang mampu bersaing di pasar untuk mempercepat laju pertumbuhan ekonomi. Salah satu program pemerintah melalui Disperinaker dalam memajukan IKM, yaitu pengadaan pelatihan keterampilan kepada masyarakat. Pada kegiatan pelatihan tersebut peserta mendapatkan pembinaan secara langsung mengenai industri kreatif aneka kerajinan, seperti hantaran, logam dan perhiasan, alat olahraga, gerabah, souvenir, aksesoris, serta pengolahan ban bekas. Selain itu, peserta IKM yang memiliki potensi pasar akan mendapatkan bantuan perluasan jaringan agar dapat terhubung ke pembeli secara langsung, informasi supplier guna pemenuhan bahan baku, serta perizinan usaha ke Dinas Perdagangan dan UMKM setempat.

Hubungan Disperinaker dan IKM tidak terlepas dari hubungan bisnis yang didasari dengan pertukaran jaringan secara kompleks. Hubungan bisnis tidak hanya didasarkan pada sarana moneter, namun juga melibatkan aktivitas timbal balik dari dua mitra bisnis atau lebih yang mungkin saja memiliki hubungan teknis yang berbeda satu sama lain [1]. Dalam menjalin hubungan antara Disperinaker dan IKM tentu dipengaruhi oleh faktor-faktor yang dapat memperluas maupun memperkecil lingkup suatu IKM.

Instansi pemerintah memiliki kemampuan dalam hal supply chain management information karena memberikan nilai kepada masyarakat dengan lebih cepat dan efektif [2]. Salah satu hal yang membentuk supply chain information yaitu peraturan pemerintah dan lingkungan hidup [3]. Informasi dan koordinasi akan berlangsung secara terpisah yang berarti menunjukkan bahwa kelangsungan supply chain bergantung pada berbagai pihak. Supply chain information merupakan area yang penting karena keberhasilan dan kegagalan bergantung pada banyak faktor, termasuk kebijakan pemerintah. Supply chain information ini dapat terjadi di Disperinaker dalam berbagai bentuk informasi kepada IKM dengan tujuan pengembangan IKM pada program peningkatan keterampilan melalui pelatihan dan promosi hasil produk.

Penelitian sebelumnya menyatakan bahwa hubungan bisnis yang terjadi melibatkan aktivitas timbal balik antar mitra bisnis sehingga hubungan bisnis antara IKM dan Pemerintahan sangat mungkin terjadi. Oleh karena itu perlu dilakukan penelitian terkait pengaruh faktor sosial, budaya, teknologi, waktu dan geografis terhadap hubungan bisnis antara Disperinaker dan IKM. Supply chain information pada Disperinaker memiliki tujuan tidak hanya untuk menyatukan metode berbagi informasi yang ada, tetapi juga menghasilkan solusi baru yang memungkinkan informasi disampaikan secara tepat, memberikan efisiensi, kecepatan informasi serta transparansi informasi antara Disperinaker dan IKM demi terwujudnya pelayanan yang berkualitas.

Penelitian ini bertujuan untuk melihat dan menjelaskan bagaimana pengaruh antara Disperinaker dan IKM dari faktor sosial, budaya, teknologi, waktu dan geografis terhadap hubungan bisnis kemudian melakukan analisis terhadap Supply Chain Information yang terjadi antara Disperinaker dan IKM menjelaskan arus informasi yang terjadi antar kedua belah pihak. Penelitian ini diharapkan mampu menjabarkan pengaruh sosial, budaya, teknologi, waktu dan geografis terhadap hubungan bisnis serta melakukan analisis terkait Supply Chain Information yang terjadi antara Disperinaker dan IKM.

\section{Tinjauan Literatur}

\section{Business Relationship}

Pendekatan bisnis dibangun dari hubungan bisnis yang berkelanjutan antara dua pihak tertentu yang berarti menerima bahwa masa depan untuk hubungan tersebut dikembangkan bersama oleh 
kedua pihak yang terlibat [1]. Hubungan bisnis tidak hanya didasarkan pada hasil keuntungan semata, tetapi juga melibatkan aktivitas timbal balik dari dua mitra bisnis bahkan mungkin memiliki hubungan teknis yang berbeda satu sama lain [4]. Bisnis yang didasarkan pada hubungan, berbeda dengan bisnis transaksional yang hanya melakukan pertukaran fungsional tanpa melibatkan perhatian jangka panjang. Hubungan yang erat antar kelompok bisnis menjadi sumber utama bagi perusahaan untuk memperoleh efisiensi dalam kegiatan pemasarannya.

Masa depan hubungan bisnis dicerminkan oleh harapan para pihak terkait akan kelangsungan bisnis yang memberikan orientasi jangka panjang untuk tindakan dalam hubungan tersebut [1], integrasi antar organisasi dicapai dengan kesepakatan dan timbal balik antara organisasi yang terlibat, Lawrence dan Lorsch menyatakan "integrasi adalah kualitas keadaan dari kolaborasi yang ada di antara departemen yang dibutuhkan untuk mencapai kesatuan usaha dengan tuntutan lingkungan" Dasar integrasi adalah kontak dan komunikasi yang intensif, dan kemauan untuk bekerja sama, yang di mana ini mengacu pada cara menyatukan perusahaan dengan interaksi, seperti kontak intensif dan aktivitas bersama [1].

Pertukaran sosial antara perusahaan yang saling berinteraksi merupakan sebuah inti dari suatu hubungan, interaksi sosial merupakan suatu perwujudan dari modal sosial [5], interaksi ini dapat membuat sebuah perusahaan terintegrasi satu sama lain, di dalam interaksi terdapat komunikasi, yang di mana komunikasi itu adalah suatu mekanisme kunci untuk mencapai integrasi dan koordinasi kegiatan unit khusus di berbagai tingkat dalam organisasi [6]. Komunikasi pada perusahaan adalah "fungsi manajemen yang menawarkan kerangka kerja agar terjadi koordinasi yang efektif dari semua komunikasi internal maupun eksternal dengan tujuan untuk membangun dan mempertahankan reputasi yang baik dengan kelompok yang terkait [7]. Komunikasi memungkinkan terjadinya pertukaran informasi antar perusahaan yang akan memberikan dampak positif terhadap perusahaan, koordinasi yang efektif dapat membuat hubungan bisnis berjalan dengan baik sesuai dengan rencana, meningkatkan profit dan lain sebagainya. Komunikasi yang baik di dalam internal perusahaan juga dapat meningkatkan kinerja semua pihak yang terlibat.

Budaya salah satu komponen kunci dalam bisnis dan berdampak pada arah hubungan bisnis. Budaya merupakan suatu pemrograman kolektif dari pikiran yang membedakan anggota suatu kelompok dari yang lain. Istilah software of the mind digunakan untuk menyebutkan keseluruhan pola dalam kajian budaya [8]. Menurut teori komunikasi antar budaya, komunikasi dengan budaya memiliki hubungan sangat erat, communication is culture and culture is communication. Ada dua jenis budaya bisnis yang dapat dibedakan [9]: Budaya konteks tinggi (high context culture) yaitu sikap dan keadaan lebih penting dari pada apa yang sebenarnya dikatakan. Budaya konteks rendah (low context culture) yaitu mitra dengan jelas mengatakan apa yang di maksud, bahasanya langsung dan jelas dan tidak ada ambiguitas. Budaya mempengaruhi keputusan manajemen dan semua fungsi bisnis dari akuntansi hingga produksi. Pada suatu kelompok atau individu perlu memiliki pengetahuan tentang aturan dan perilaku kebiasaan yang dianggap dapat diterima dalam hubungan sosial dan profesional. Budaya dan tradisi masing-masing individu dan kelompok membuat orang berperilaku berbeda dan jika individu atau kelompok tidak bisa beradaptasi dengan perbedaan budaya bisnis, maka dapat menyebabkan penolakan di pihak lain dan bahkan membahayakan keberhasilan negosiasi.

Teknologi informasi digunakan dalam hubungan bisnis sebagai hasil dari niat bersama untuk meningkatkan arus informasi, berkaitan erat dengan integrasi antar perusahaan yang didasari oleh kontak dan komunikasi intensif [1]. Teknologi informasi digunakan untuk meningkatkan, memperbaiki, memperbesar aliran atau transfer data dan informasi, meskipun aspek teknis dari teknologi informasi berbeda - beda. Beberapa peneliti menyatakan bahwa penggunaan teknologi informasi membuat transaksi bisnis antara dua perusahaan lebih efisien, dengan menurunkan biaya, Menggunakan teknologi informasi untuk pertukaran informasi atau bahkan transaksi ekonomi adalah cara berkomitmen, karena menuntut penguasaan teknologi informasi serta mempelajari cara menggunakannya dan menyesuaikan hubungan bisnis dengannya [1], teknologi dapat mempermudah kontak antar perusahaan, menjadikan pertukaran informasi dan transaksi menjadi lebih mudah, efisien dan hemat biaya.

Pendekatan waktu untuk bisnis dibagi menjadi waktu horizontal (yaitu hubungan masa lalu, sekarang, dan masa depan) dan waktu vertikal (yaitu variasi dalam perspektif sosial, organisasi, dan budaya) [10]. Penguatan interaksi masa lalu dan masa depan memiliki implikasi penting bagi 
hubungan bisnis. Setidaknya ada tiga cara interaksi saat ini dapat diperiksa berkaitan dengan hubungan bisnis. Pertama, ada cara-cara di mana waktu mengandung interaksi bisnis; kedua, cara waktu menyebar atau mengukur interaksi bisnis; dan ketiga bagaimana kesadaran waktu, baik masa lalu maupun masa depan, digunakan sebagai acuan untuk memahami interaksi bisnis [10]. Masa kini dari setiap hubungan dikondisikan oleh masa lalu dan masa depan. Pemisahan waktu ke masa lalu, sekarang, dan masa depan memberikan ukuran dan urutan peristiwa. Jadi, pelaku bisnis atau perusahaan dapat merencanakan kegiatan koordinasi antar bisnis dan hubungan sumber daya untuk waktu yang akan datang. Demikian juga, kelompok bisnis dapat berunding dengan aspek waktu lampau yang diingat, atau kelompok bisnis dapat berinteraksi dengan partner lain saat ini mengenai aktivitas masa lalu, tetapi tidak dapat berinteraksi di masa lalu.

Pendekatan geografis bersifat relatif yang bergantung pada faktor-faktor seperti komunikasi dan peraturan. Geografis juga merupakan konsep subjektif, hal ini tergantung pada penilaian individu berdasarkan data objektif (jarak, waktu, harga) [11]. Pendekatan geografis dalam hubungan antar bisnis paling sering dikaitkan dengan pengaruhnya terhadap jarak dan lokasi. Jika berada dalam kondisi bisnis yang memiliki persaingan yang ketat, faktor lokasi merupakan komponen yang sangat penting. Agar bisnis yang dijalankan dapat bersaing secara efisien, maka diperlukan lokasi bisnis yang strategis yang mudah dijangkau oleh mitra bisnis dan konsumen. Ketepatan pemilihan lokasi menjadi salah satu faktor penentu kesuksesan sebuah hubungan antar bisnis. Jarak berkaitan erat dengan arti lokasi dan upaya pemenuhan kebutuhan atau keperluan pokok (air, tanah subur, pusat pelayanan), pengangkutan barang. Semakin dekat jarak geografis antar bisnis, maka semakin mudah pula pengendaliannya.

Pada penelitian yang dilakukan oleh [12] mengenai peran Dinas Perindustrian dan Perdagangan dalam pemberdayaan pengrajin memiliki tujuan yaitu Dinas Perindustrian dan Perdagangan memotivasi para pengrajin perak melalui program pelatihan dan pembinaan serta perizinan badan usaha agar perak menjadi komoditas yang unggul. Hasil dari penelitian ini memiliki kesimpulan terdapat faktor yang menjadi pendukung dan penghambat dalam pemberdayaan IKM. Faktor pendukung yakni tenaga kerja yang banyak dan masih belum banyak yang memiliki usaha yang sama, sedangkan faktor penghambat yakni bahan baku yang mahal, kualitas sumber daya manusia yang rendah, dan terbatasnya modal.

Pada penelitian selanjutnya dilakukan oleh [13] mengenai peranan Dinas Perindustrian, Perdagangan, Koperasi (Disperindagkop) dan UKM dalam mempromosikan produk IKM memiliki tujuan yaitu mengetahui peran Disperindagkop dan UKM dalam promosi produk IKM, selain itu acara pameran expo yang difasilitasi dan diselenggarakan oleh pihak Disperindagkop dan UKM agar IKM dapat mempromosikan produknya. Hasil dari penelitian menunjukkan bahwa Disperindagkop dan UKM memiliki peran dalam memasarkan barang-barang IKM melalui berbagai bentuk pameran. IKM yang dibina oleh Disperindagkop \& UKM biasanya ditangani pada unit bidang industri. Salah satu pameran yang berlangsung di tahun 2014 adalah pagelaran pertumbuhan industri kreatif.

Pada penelitian yang dilakukan oleh [14] dijelaskan mengenai peranan pemerintah dalam pembinaan dan pengembangan IKM. Tujuan dari penelitian ini adalah mengetahui peran Dinas Perindustrian dan Perdagangan dalam kegiatan promosi, monitoring, dan pelatihan. Hasil penelitian menunjukkan bahwa terdapat faktor penghambat dalam pelaksanaan pengembangan dan pembinaan IKM. Dinas Perindustrian dan Perdagangan telah melakukan upaya dalam menangani hambatan tersebut.

Sedangkan pada penelitian ini akan melihat pengaruh sosial, budaya, teknologi, waktu dan geografis terhadap hubungan bisnis dengan mengoperasionalkan kelima variabel sosial, budaya, teknologi, waktu dan geografis sebagai variabel independen dan hubungan bisnis sebagai variabel dependen. Melihat kontribusi kelima variabel tersebut secara bersamaan dalam memberikan pengaruh hubungan bisnis.

\section{Supply Chain Management (SCM)}

Supply Chain merupakan organisasi yang terlibat dalam berbagai proses dan aktivitas yang menghasilkan nilai dalam bentuk produk dan layanan ke konsumen akhir. Supply Chain Management (SCM) berkaitan dengan manajemen terintegrasi arus barang dan informasi dari konsumen akhir melalui pemasok asli yang menyediakan produk, layanan, dan informasi, untuk memastikan bahwa 
pengiriman barang yang tepat pada tempat dan kuantitas yang tepat di waktu yang tepat [15]. Supply Chain Management (SCM) melibatkan berbagai bidang, seperti forecasting, pengadaan, produksi, distribusi, inventaris, transportasi, dan layanan pelanggan, yang dibahas dalam beberapa perspektif perencanaan, yaitu strategis, taktis, dan operasional [16].

Pemerintah dan layanan organisasi publik memiliki potensi terhadap supply chain management karena memberikan suatu nilai kepada masyarakat secara lebih efisien dan efektif. Penelitian mengenai supply chain management telah diketahui bahwa pentingnya mempertahankan usaha kecil di pasar pasokan [17], hal yang penting bahwa usaha kecil relatif dirugikan oleh organisasi yang lebih besar dalam hubungan pertukaran dan komunikasi elektronik, keduanya merupakan hal yang penting dari hubungan pemasok [18]. Mengatasi hal ini, pemerintah mengembangkan usaha kecil melalui peningkatan keterlibatan dengan kontrak sektor pabrik.

\section{Supply Chain Information}

Berbagi informasi berarti mendistribusikan informasi yang berguna untuk sistem, orang, atau unit organisasi. Untuk meningkatkan hasil dari berbagi informasi, organisasi harus mempersiapkan empat hal utama: Pertama informasi apa yang harus dibagikan, lalu dengan siapa informasi akan dibagikan, lalu bagaimana cara berbagi informasi, dan terakhir kapan harus berbagi [19]. Istilah 'Berbagi Informasi' juga bisa disebut sebagai 'Berbagi Pengetahuan' atau 'Integrasi Informasi'. Ada banyak sekali informasi dalam sebuah supply chain, seperti, logistik, bisnis, strategis, taktis dan banyak lagi. Dampak berbagi informasi pada supply chain menjadi lebih signifikan baru baru ini dengan kemajuan Teknologi Informasi (TI). Beberapa investigasi telah dilakukan untuk fokus pada dampak berbagi informasi tentang kualitas produk. Namun, masih ada ruang untuk studi lebih lanjut untuk mengklarifikasi dengan tepat bagaimana dan informasi apa yang harus dibagikan dan efek menguntungkan pada peningkatan kualitas [19]. Banyak contoh perusahaan dalam supply chain yang mendapat manfaat dari berbagi permintaan dan informasi perkiraan, tetapi mereka menunjukkan, berdasarkan studi empiris, bahwa manfaat berbagi informasi dapat sangat bervariasi di antara berbagai pihak dalam supply chain [20].

Pada penelitian yang dilakukan oleh [21] membahas analisis pengaruh supply chain terhadap kinerja industri kecil dan menengah yang memiliki tujuan untuk menganalisis pengaruh manajemen supply chain. Hasil pada penelitian ini menunjukkan variabel berbagi informasi, hubungan jangka panjang, kerja sama, dan integrasi proses berpengaruh positif dan signifikan terhadap supply chain information pada IKM. Penelitian selanjutnya dilakukan oleh [22] membahas mengenai integrasi supply chain information yang memiliki tujuan untuk mengetahui dampak dari Supply Chain Information Integration (SCII) terhadap kinerja operasional perusahaan manufaktur. Hasil penelitian ini menunjukkan bahwa kualitas informasi, keamanan informasi, dan teknologi informasi (TI) berpengaruh positif terhadap Supply Chain Information Integration. Penelitian ini memberikan pengetahuan tentang kesulitan yang dihadapi saat menerapkan supply chain information, terutama oleh perusahaan manufaktur menengah.

Sedangkan pada penelitian ini akan dilakukan analisis supply chain information yang terjadi antara Disperinaker dan IKM. Analisis dilakukan dengan wawancara secara langsung pada pihak Disperinaker sehingga penelitian ini akan menghasilkan solusi baru yang memungkinkan informasi disampaikan secara tepat, memberikan efisiensi, kecepatan informasi serta transparansi informasi antara Disperinaker dan IKM demi terwujudnya pelayanan yang berkualitas.`

\section{Metode Penelitian}

Penelitian ini menggunakan mixed methods (metode campuran) dengan metode kuantitatif sebagai metode primer. Mixed method merupakan suatu prosedur untuk mengumpulkan, menganalisis, dan mencampur metode kuantitatif dan kualitatif dalam suatu penelitian secara bersamaan ataupun sekuensial [23] sehingga diperoleh data yang lebih komprehensif, valid, reliabel dan objektif. Penelitian ini menggunakan tipe desain convergent parallel dengan mengumpulkan dan menganalisis data penelitian baik kualitatif maupun kuantitatif dalam waktu yang bersamaan [24] kemudian menggabungkan dan mendeskripsikan hasil temuan keduanya secara detail. Data kuantitatif diambil untuk mengetahui hubungan bisnis antara Disperinaker dan IKM Kabupaten Tegal, sedangkan data kualitatif digunakan untuk mengeksplorasi lebih dalam terkait supply chain 
information diantara Disperinaker dan IKM Kabupaten Tegal. Tahapan dalam metode penelitian mixed methods divisualisasikan pada Gambar 1.

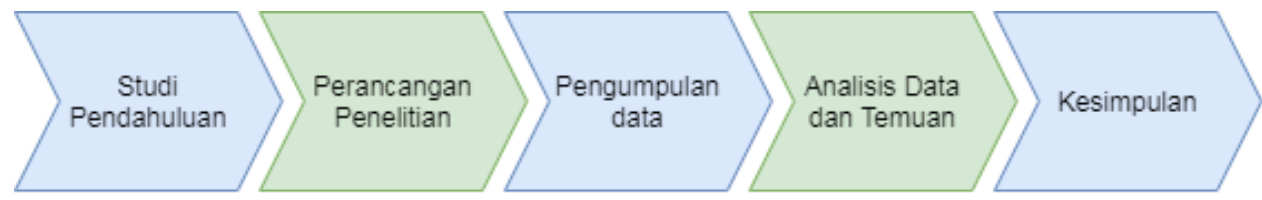

Gambar 1. Tahapan Penelitian

\section{Tahap Studi Pendahuluan}

Pada tahap awal penelitian dilakukan identifikasi masalah terkait hubungan bisnis yang terjalin antara Disperinaker dan IKM serta informasi awal mengenai supply chain information. Selanjutnya dari masalah tersebut dibentuk rumusan masalah dan tujuan penelitian.

\section{Tahap Perancangan Penelitian}

Pada tahap perancangan penelitian dilakukan pengumpulan data dan informasi yang dibutuhkan dalam penelitian serta penentuan lokasi penelitian. Kegiatan yang dilakukan meliputi studi literatur dari sumber tulisan yang pernah dibuat terkait permasalahan penelitian ini, penentuan operasional variabel dan penyusunan instrumen penelitian. Selanjutnya pemilihan lokasi penelitian yaitu Kabupaten Tegal yang didasari dengan adanya temuan bahwa Disperinaker Kabupaten Tegal memiliki program pelatihan untuk memfasilitasi IKM dalam melakukan pengembangan usaha. Berdasarkan temuan tersebut dapat dianalisa terkait faktor-faktor yang mempengaruhi hubungan bisnis antara Disperinaker dengan IKM Kabupaten Tegal dan supply chain information yang terjadi di dalamnya.

\section{Tahap Pengumpulan Data}

Pada tahap ketiga dilakukan proses pengumpulan data dengan teknik survei melalui penyebaran kuesioner dan teknik deep interview. Pengumpulan data melalui kuesioner ditujukan pada sampel yang dipilih secara random dari populasi penelitian untuk memperoleh data kuantitatif. Populasi dari penelitian adalah pelaku IKM kategori aneka kerajinan yang berjumlah 252 IKM. Pada studi ini, diterapkan teknik random sampling dalam menentukan sampel penelitian karena anggota populasi bersifat homogen [25], sehingga memiliki peluang yang sama untuk dipilih. Jumlah sampel minimum dalam penelitian ini dihitung menggunakan persamaan 1 .

$n=\frac{\mathrm{N}}{\mathrm{N} \cdot d^{2}+1}$

dengan $\mathrm{n}$ merupakan jumlah sampel, $\mathrm{N}$ merupakan jumlah populasi, dan $\mathrm{d}^{2}$ merupakan presisi yang ditetapkan. Berdasarkan persamaan 1, maka diperoleh jumlah sampel minimum IKM kategori aneka kerajinan sebesar 25 responden.

Sedangkan untuk pengumpulan data kualitatif dilakukan proses deep interview kepada responden. Teknik pengambilan sampel yang digunakan adalah purposive sampling karena pertimbangan tertentu [26], yaitu kebutuhan dalam kedalaman informasi tentang prosedur kegiatan peningkatan keterampilan bagi IKM dan supply chain information antara Disperinaker dan IKM. Berdasarkan pertimbangan tersebut, responden untuk sumber data kualitatif yang dipilih yaitu Kepala Bidang Industri Agro karena memiliki tugas pokok dan fungsi dalam pengelolaan bidang industri.

\section{Tahap Analisis Data}

Pada tahap awal analisis data akan dilakukan pengujian nilai validitas dan reliabilitas dari alat ukur atau instrumen yang digunakan. Suatu alat ukur yang validitasnya tinggi akan mempunyai tingkat kesalahan kecil sehingga data yang terkumpul merupakan data yang memadai [23]. Perhitungan korelasi pada uji validitas menggunakan korelasi Pearson Product Moment dapat diuraikan pada persamaan 2 . 


$$
r=\frac{n \Sigma X_{i} Y_{i}-\left(\Sigma X_{i}\right)\left(\Sigma Y_{i}\right)}{\sqrt{\left\{n \Sigma X_{i}^{2}-\left(\Sigma X_{i}\right)^{2}\right\}\left\{n \Sigma Y_{i}^{2}-\left(\Sigma Y_{i}\right)^{2}\right\}}}
$$

Keterangan:

$\mathrm{r}=$ koefisien korelasi product moment

$X_{i}=$ variabel independen

$\mathrm{X}_{\mathrm{i}} \mathrm{Y}_{\mathrm{i}}=$ jumlah perkalian variabel bebas dan variabel terikat

$Y_{i}=$ variabel dependen

$\mathrm{n}=$ jumlah responden

Sebuah alat ukur dikategorikan reliabel (handal) jika dapat mengukur secara konsisten atau stabil meskipun diajukan dalam waktu yang berbeda [23]. Semua instrumen dikatakan reliabel jika nilai Cronbach alpha lebih besar dari batasan yang telah ditentukan yaitu 0,6. Untuk melihat reliabilitas masing-masing instrument digunakan koefisien Cronbach alpha yang diuraikan pada persamaan 3.

$$
a=\frac{k}{k-1}\left(1-\frac{\Sigma \mathrm{s}_{\mathrm{i}}}{s_{t}}\right)
$$

Keterangan :

$\alpha=$ koefisien reliabilitas $\quad S_{\mathrm{i}}=$ jumlah varian skor tiap item

$\mathrm{k}=$ jumlah item pertanyaan yang diuji $\quad \mathrm{S}_{\mathrm{t}}=$ varians total

Pada penelitian ini, metode analisis yang digunakan untuk menghitung pengaruh sosial, budaya, teknologi, waktu dan geografis terhadap hubungan bisnis adalah metode regresi berganda dengan menggunakan tools RGui. Regresi berganda atau multiple linear regression merupakan model regresi yang bertujuan untuk mencari hubungan linear antara sebuah variabel dependen dan lebih dari satu variabel independen [27]. Perhitungan regresi linear berganda diuraikan pada persamaan 4.

$Y=a+b_{1} X_{1}+b_{2} X_{2}+b_{3} X_{3}+b_{4} X_{4}+b_{5} X_{5}+\varepsilon$

Keterangan:

$\mathrm{Y}=$ variabel hubungan bisnis

$\mathrm{X}_{3}=$ variabel teknologi

$\mathrm{a}=$ konstanta

$\mathrm{X}_{4}=$ variabel waktu

$b_{1}, b_{2}, b_{3}, b_{4}, b_{5}=$ koefisien regresi variabel independen

$X_{l}=$ variabel sosial

$\mathrm{X}_{5}=$ variabel geografis

$X_{2}=$ variabel budaya

$\varepsilon=$ standar error

\section{Operasional Variabel}

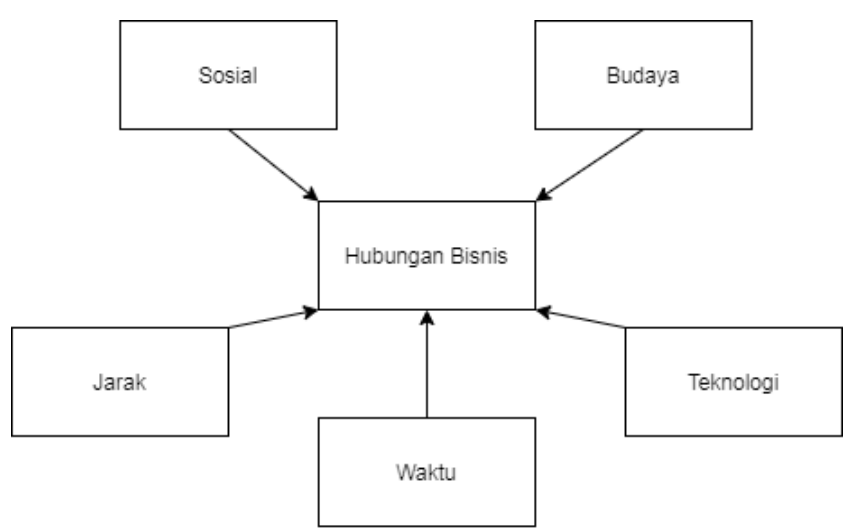

Gambar 2. Variabel Penelitian 
Variabel merupakan suatu atribut atau sifat atau nilai dari orang, objek atau kegiatan yang mempunyai variasi tertentu yang ditetapkan oleh peneliti untuk dipelajari dan kemudian ditarik kesimpulannya [26]. Variabel dalam penelitian ini terdiri dari variabel dependen dan variabel independen yang divisualisasikan pada Gambar 2. Variabel dependen berupa tingkat hubungan bisnis antara Disperinaker dan IKM, sedangkan variabel independen berupa 5 (lima) faktor yang mempengaruhi hubungan bisnis. Tabel 1 menunjukkan 5 (lima) variabel independen yang dijabarkan menjadi dimensi turunan berdasarkan literatur terkait penelitian ini.

Tabel 1. Variabel Independen dan Dimensi Turunan

\begin{tabular}{clll}
\hline No & Variabel & Dimensi & Studi Pustaka \\
\hline 1. & Sosial & Komunikasi & Olkkonen et all (2000) \\
\hline 2. & Budaya & Aturan & Geiger \& Kleinaltenkamp \\
& & Kebiasaan & Lindh (2006) \\
\hline 3. & Teknologi & Kontak & \\
& & Informasi & Transaksi \\
& & Ukuran & Medlin (2004) \\
\hline 4. & Waktu & Masa lalu & Johanson (2005) \\
\hline 5. & Geografis & Jarak &
\end{tabular}

Hubungan bisnis ini dapat diasumsikan sebagai hasil dari komunikasi dan pertukaran sosial yang terjadi secara pararel [28]. Peristiwa pertukaran sosial terkait dengan pertukaran ekonomi, hukum dan informasi serta termasuk dalam proses koordinasi dan adaptasi yang sedang berlangsung. Kemudian variabel budaya di operasionalkan menjadi beberapa lapisan, di antaranya aturan dan kebiasaan [9]. Teknologi hadir untuk mengintegrasikan antar bisnis, dasarnya integrasi itu adalah kontak intensif dan komunikasi serta keinginan untuk saling bekerja sama [1]. Teknologi informasi digunakan dalam hubungan bisnis untuk kontak sosial, pertukaran informasi tentang pemesanan atau pengiriman, informasi tentang produk dan akhirnya untuk transaksi ekonomi. Waktu dapat mengukur dua peristiwa yang sama persis, waktu berhubungan dengan masa lalu [10]. Pemisahan waktu terhadap masa lalu memberikan ukuran dan urutan peristiwa. Waktu mengukur interaksi bisnis dan waktu sebagai masa lalu digunakan sebagai acuan untuk memberi pengetahuan interaksi bisnis. Kedekatan geografis dipengaruhi oleh jarak geografis terhadap mitra bisnis seperti pelanggan dan pemasok [11]. Hubungan bisnis dapat diasumsikan sebagai hasil dari komunikasi dan pertukaran sosial yang terjadi secara pararel. Peristiwa pertukaran sosial terkait dengan pertukaran ekonomi, hukum dan informasi serta termasuk dalam proses koordinasi dan adaptasi yang sedang berlangsung.

\section{$4 \quad$ Hasil dan Pembahasan}

\section{Analisis Data}

Pada bagian analisis data ini akan menjabarkan hasil temuan serta fakta yang ditemukan selama penelitian ini berlangsung dan melakukan analisis dari temuan tersebut. Berdasarkan hasil penyebaran kuesioner yang dilakukan kepada IKM, data yang didapat pada penelitian ini sebanyak 28 responden. Berdasarkan persamaan 1, jumlah tersebut telah memenuhi kriteria minimum sampel penelitian yaitu 25 responden. Kemudian penelitian ini menemukan data berdasarkan hasil wawancara kepada narasumber dari Disperinaker dan akan dijelaskan serta di analisis dari temuan tersebut.

Pengujian validitas digunakan untuk mengukur kelayakan instrumen. Kriteria pengujian validitas dilakukan dengan membandingkan $r$ hitung dengan $r$ tabel dengan $\alpha=0,05$. Apabila hasil perhitungan $r$ hitung $\geq r$ tabel maka penilaian tersebut di nilai valid, namun apabila $r$ hitung $\leq r$ tabel maka dinilai tidak valid, sehingga pernyataan pada kuesioner tersebut tidak dapat digunakan dalam penelitian. Tabel 2 menampilkan hasil uji validitas dari setiap butir pertanyaan pada kuesioner. 
Tabel 2. Hasil Uji Validitas

\begin{tabular}{cccccc}
\hline $\begin{array}{c}\text { Pertanyaa } \\
\mathbf{n}\end{array}$ & $\begin{array}{c}\text { Nilai } \\
\text { Validitas }\end{array}$ & $\begin{array}{c}\text { Keteranga } \\
\mathbf{n}\end{array}$ & $\begin{array}{c}\text { Pertanyaa } \\
\mathbf{n}\end{array}$ & $\begin{array}{c}\text { Nilai } \\
\text { Validitas }\end{array}$ & $\begin{array}{c}\text { Keterang } \\
\text { an }\end{array}$ \\
\hline 1 & 0.756 & Valid & 14 & 0.890 & Valid \\
\hline 2 & 0.736 & Valid & 15 & 0.948 & Valid \\
\hline 3 & 0.758 & Valid & 16 & 0.809 & Valid \\
\hline 4 & 0.783 & Valid & 17 & 0.864 & Valid \\
\hline 5 & 0.749 & Valid & 18 & 0768 & Valid \\
\hline 6 & 0.775 & Valid & 19 & 0.867 & Valid \\
\hline 7 & 0.513 & Valid & 20 & 0.793 & Valid \\
\hline 8 & 0.788 & Valid & 21 & 0.777 & Valid \\
\hline 9 & 0.785 & Valid & 22 & 0.751 & Valid \\
\hline 10 & 0.894 & Valid & 23 & 0.785 & Valid \\
\hline 11 & 0.907 & Valid & 24 & 0.866 & Valid \\
\hline 12 & 0.886 & Valid & 25 & 0.871 & Valid \\
\hline 13 & 0.947 & Valid & 26 & 0.869 & Valid \\
\hline
\end{tabular}

Berdasarkan pengujian validitas data kuesioner dari 28 responden, didapat nilai $r$ tabel sebesar 0.374. Nilai $\mathrm{r}$ tabel tersebut menjadi acuan dalam menentukan validitas setiap pertanyaan pada kuesioner. Pada Tabel 2, nilai $r$ hitung dari setiap pertanyaan menunjukkan angka di atas 0.374 atau dapat dikatakan $r$ hitung $>r$ tabel sehingga setiap pertanyaan dalam kuesioner dinyatakan valid.

Pengujian reliabilitas dari 26 butir pertanyaan kuesioner menghasilkan angka cronbach alpha sebesar 0,979 pada Tabel 3. Angka tersebut lebih besar dari nilai minimal cronbach alpha yaitu 0,6, sehingga dapat disimpulkan bahwa pernyataan dari kuesioner yang digunakan untuk mengukur variabel dikatakan reliabel atau handal.

Tabel 3. Hasil Uji Reliabilitas

\begin{tabular}{cc}
\hline Cronbach's Alpha & N of Items \\
\hline 0,979 & 26 \\
\hline
\end{tabular}

\section{Analisis Hubungan Bisnis}

Berdasarkan data kuesioner dengan responden $28 \mathrm{IKM}$, diperoleh data berupa usia, jenis usaha dan omzet dari masing-masing IKM yang divisualisasikan dengan pie chart. Pada Gambar 3 menunjukkan bahwa pie chart sebaran usia pelaku usaha IKM berada pada angka $24-59$ tahun dengan sebagian besar berusia 39 dan 41 tahun. Kemudian pada Gambar 3 juga terdapat pie chart sebaran jenis usaha yang dimiliki oleh IKM cukup bervariatif dan sebagian besar bergerak di bidang pembuatan alat olahraga, kerajinan kulit dan kerajinan limbah.
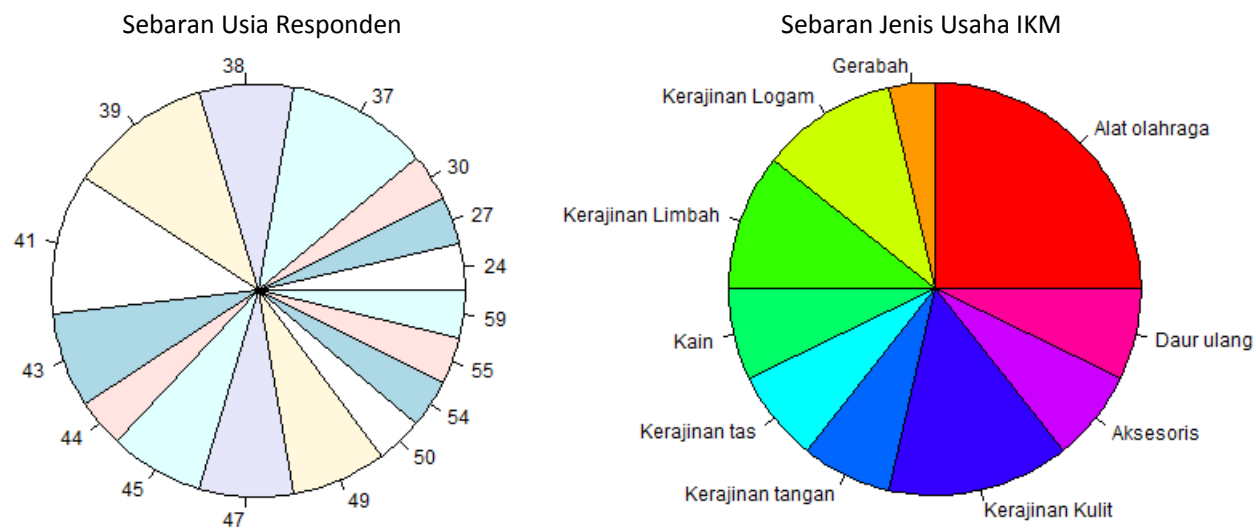

Gambar 3. Pie Chart Sebaran Usia Responden dan Jenis Usaha IKM 
Gambar 4 menunjukkan data kisaran omzet IKM yang digambarkan dengan skala persen. Rentang omzet berkisar Rp.20.000.000 hingga > Rp.100.000.000 dengan sebagian besar responden IKM memiliki omzet berikisar Rp.20.000.000 - Rp.39.000.000 dan selanjutnya kedua terbanyak IKM memiliki omzer berkisar Rp.40.000.000 - Rp. 59.000.000.

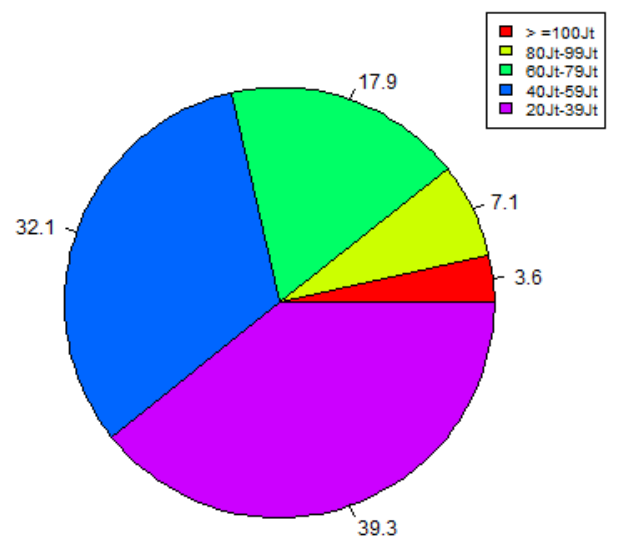

\section{Gambar 4. Pie Chart Kisaran Omzet IKM}

Selain data sebaran di atas, terdapat beberapa temuan di lapangan tentang IKM yaitu: (1) ratarata IKM memerlukan pihak lain dalam produksi atau pembuatan sebuah produk, (2) manajemen bisnis pada IKM sebagian besar telah menggunakan suatu aplikasi, serta (3) IKM telah menggunakan teknologi dalam hubungan interaksi antar rekan bisnis dan proses transaksi pembayaran. Sebagian IKM telah menggunakan marketplace dan media sosial dalam menawarkan produk, namun penggunaan website sebagai media untuk menawarkan dan memberikan informasi terkait produk belum digunakan. Pelaku IKM lebih banyak yang sudah terbiasa dengan penggunaan teknologi dalam kehidupan sehari-hari.

Tabel 4. Hasil Kuesioner IKM

\begin{tabular}{|c|c|c|c|c|c|c|}
\hline \multirow{2}{*}{ No } & \multirow{2}{*}{ Pernyataan } & \multicolumn{5}{|c|}{ Skala Jawaban } \\
\hline & & 5 & 4 & 3 & 2 & 1 \\
\hline A. & Faktor Sosial & & & & & \\
\hline 1. & $\begin{array}{l}\text { Komunikasi yang baik mempengaruhi hubungan bisnis } \\
\text { antara Disperinaker dan IKM }\end{array}$ & 9 & 14 & 5 & 0 & 0 \\
\hline 2. & $\begin{array}{l}\text { Intensitas komunikasi mempengaruhi hubungan bisnis } \\
\text { antara Disperinaker dan IKM }\end{array}$ & 7 & 14 & 7 & 0 & 0 \\
\hline 3. & $\begin{array}{l}\text { Kejujuran dalam berkomunikasi mempengaruhi } \\
\text { hubungan bisnis antara Disperinaker dan IKM }\end{array}$ & 9 & 13 & 6 & 0 & 0 \\
\hline 4. & $\begin{array}{l}\text { Timbal balik dalam komunikasi mempengaruhi } \\
\text { hubungan bisnis antara Disperinaker dan IKM }\end{array}$ & 7 & 15 & 6 & 0 & 0 \\
\hline B. & Faktor Budaya & & & & & \\
\hline 1. & $\begin{array}{l}\text { Budaya pelayanan prima mempengaruhi hubungan bisnis } \\
\text { antara Disperinaker dan IKM }\end{array}$ & 7 & 14 & 7 & 0 & 0 \\
\hline 2. & $\begin{array}{l}\text { Tertib administrasi mempengaruhi hubungan bisnis } \\
\text { antara Disperinaker dan IKM }\end{array}$ & 6 & 14 & 8 & 0 & 0 \\
\hline 3. & $\begin{array}{l}\text { Keramahan mempengaruhi hubungan bisnis antara } \\
\text { Disperinaker dan IKM }\end{array}$ & 6 & 14 & 7 & 0 & 1 \\
\hline 4. & $\begin{array}{l}\text { Etos kerja mempengaruhi hubungan bisnis antara } \\
\text { Disperinaker dan IKM }\end{array}$ & 6 & 14 & 8 & 0 & 0 \\
\hline 5. & $\begin{array}{l}\text { Surat Penawaran/Kontrak Kerjasama mempengaruhi } \\
\text { hubungan bisnis antara Disperinaker dan IKM }\end{array}$ & 6 & 12 & 10 & 0 & 0 \\
\hline
\end{tabular}




\begin{tabular}{|c|c|c|c|c|c|c|}
\hline \multirow{2}{*}{ No } & \multirow{2}{*}{ Pernyataan } & \multicolumn{5}{|c|}{ Skala Jawaban } \\
\hline & & 5 & 4 & 3 & 2 & 1 \\
\hline C. & $\begin{array}{ll}\text { Faktor Teknologi } \\
\end{array}$ & & & & & \\
\hline 1. & $\begin{array}{l}\text { Pemanfaatan Sistem Informasi mempengaruhi hubungan } \\
\text { bisnis antara Disperinaker dan IKM }\end{array}$ & 4 & 6 & 16 & 2 & 0 \\
\hline 2. & $\begin{array}{l}\text { Pemanfaatan teknologi dalam kontak sosial (komunikasi) } \\
\text { bisnis mempengaruhi hubungan antara Disperinaker dan } \\
\text { IKM }\end{array}$ & 4 & 6 & 17 & 1 & 0 \\
\hline 3. & $\begin{array}{l}\text { Pemanfaatan ERP mempengaruhi hubungan bisnis antara } \\
\text { Disperinaker dan IKM }\end{array}$ & 3 & 7 & 17 & 0 & 1 \\
\hline 4. & $\begin{array}{l}\text { Pemanfaatan teknologi dalam penyampaian informasi } \\
\text { produk mempengaruhi hubungan bisnis antar mitra }\end{array}$ & 4 & 6 & 17 & 1 & 0 \\
\hline 5. & $\begin{array}{l}\text { Pemanfaatan teknologi dalam promosi usaha } \\
\text { mempengaruhi hubungan bisnis antar mitra }\end{array}$ & 3 & 7 & 17 & 0 & 1 \\
\hline 6. & $\begin{array}{l}\text { Pemanfaatan teknologi dalam transaksi jual beli } \\
\text { mempengaruhi hubungan antar mitra }\end{array}$ & 4 & 6 & 17 & 1 & 0 \\
\hline D. & Faktor Waktu & & & & & \\
\hline 1. & $\begin{array}{l}\text { Efektifitas waktu dalam proses bisnis mempengaruhi } \\
\text { hubungan antara Disperinaker dan IKM }\end{array}$ & 3 & 11 & 13 & 1 & 0 \\
\hline 2. & $\begin{array}{l}\text { Pelayanan yang cepat mempengaruhi hubungan bisnis } \\
\text { antara Disperinaker dan IKM }\end{array}$ & 5 & 10 & 13 & 0 & 0 \\
\hline 3. & $\begin{array}{l}\text { Kerjasama bisnis sebelumnya mempengaruhi hubungan } \\
\text { di masa yang akan datang antara Disperinaker dan IKM }\end{array}$ & 4 & 10 & 14 & 0 & 0 \\
\hline E. & Faktor Geografis & & & & & \\
\hline 1. & $\begin{array}{l}\text { Jarak mempengaruhi hubungan bisnis antara } \\
\text { Disperinaker dan IKM }\end{array}$ & 3 & 5 & 19 & 1 & 0 \\
\hline 2. & $\begin{array}{l}\text { Jarak mempengaruhi kemudahan komunikasi antara } \\
\text { Disperinaker dan IKM }\end{array}$ & 3 & 4 & 19 & 0 & 0 \\
\hline 3. & $\begin{array}{l}\text { Lokasi usaha yang strategis mempengaruhi hubungan } \\
\text { bisnis antara Disperinaker dan IKM }\end{array}$ & 4 & 6 & 18 & 0 & 0 \\
\hline F. & Hubungan Bisnis & & & & & \\
\hline 1. & $\begin{array}{l}\text { Hubungan bisnis antara Disperinaker dan IKM sangat } \\
\text { dibutuhkan untuk keberlangsungan bisnis }\end{array}$ & 4 & 9 & 14 & 1 & 0 \\
\hline 2. & $\begin{array}{l}\text { Hubungan bisnis antara Disperinaker dan IKM } \\
\text { memberikan keuntungan secara langsung pada bisnis }\end{array}$ & 3 & 3 & 12 & 10 & 0 \\
\hline 3. & $\begin{array}{l}\text { Hubungan bisnis antara Disperinaker dan IKM } \\
\text { memberikan keuntungan secara tidak langsung pada } \\
\text { bisnis }\end{array}$ & 5 & 4 & 17 & 2 & 0 \\
\hline 4. & $\begin{array}{l}\text { Hubungan bisnis antara Disperinaker dan IKM } \\
\text { memberikan peluang usaha untuk berkembang lebih } \\
\text { cepat }\end{array}$ & 4 & 4 & 18 & 2 & 0 \\
\hline 5. & $\begin{array}{l}\text { Hubungan bisnis antara Disperinaker dan IKM } \\
\text { mempengaruhi pertukaran sosial }\end{array}$ & 3 & 5 & 18 & 2 & 0 \\
\hline
\end{tabular}

Tabel 4 menunjukkan hasil pengisian kuesioner sebanyak 28 responden dari IKM. Kuesioner berisi 26 pertanyaan, di mana setiap pertanyaan mewakili variabel dan dimensi turunannya. Skala $1-$ 5 menunjukkan pendapat di mana nilai 5 berarti sangat setuju, 4 setuju, 3 cukup, 2 tidak setuju dan 1 sangat tidak setuju.

Pada pernyataan faktor sosial yang meliputi komunikasi, intensitas, kejujuran, dan timbal balik dalam komunikasi, rata-rata responden memberikan pendapat setuju bahwa faktor sosial memiliki pengaruh terhadap hubungan bisnis. Pada pernyataan faktor budaya yang meliputi pelayanan prima, tertib administrasi, keramahan, etos kerja, dan penawaran/kontrak kerja sama rata-rata responden memberikan pendapat setuju bahwa faktor budaya memiliki pengaruh terhadap hubungan bisnis. Pada 
pernyataan faktor teknologi, pemanfaatan sistem informasi, teknologi dalam kontak sosial, ERP, teknologi dalam penyampaian informasi, teknologi dalam promosi usaha, dan teknologi dalam transaksi jual beli rata-rata responden memberikan pendapat cukup bahwa faktor teknologi memiliki pengaruh terhadap hubungan bisnis. Pada pernyataan faktor geografis yang meliputi jarak, kemudahan komunikasi, dan lokasi usaha yang strategis rata-rata responden memberikan pendapat cukup bahwa faktor geografis memiliki pengaruh terhadap hubungan bisnis. Pada pernyataan hubungan bisnis yang meliputi keberlangsungan bisnis, keuntungan secara langsung, keuntungan secara tidak langsung, peluang usaha, dan pertukaran sosial rata-rata responden memberikan pendapat cukup bahwa terdapat hubungan bisnis antara Disperinaker dan IKM.

Dari data tersebut kemudian dilakukan analisis menggunakan regresi linear berganda sehingga menghasilkan koefisien masing-masing variabel pada Tabel 5.

Tabel 5. Hasil Uji Koefisien

\begin{tabular}{lrrr}
\hline Model & Estimate Std. & Error & Nilai t \\
\hline (Constant) & 1.09203 & 1.79578 & 0.608 \\
Sosial & -0.25023 & 0.15846 & -1.579 \\
Budaya & 0.05619 & 0.13123 & 0.428 \\
Teknologi & 0.81038 & 0.14083 & $\mathbf{5 . 7 5 4}$ \\
Waktu & -0.13093 & 0.30510 & -0.429 \\
Geografis & 0.30369 & 0.32289 & 0.941 \\
Significant codes: $\mathbf{0 . 0 5}$ & & & \\
Multiple R-squared: $\mathbf{0 . 9 0 3}$ & & & \\
\hline
\end{tabular}

Sebuah variabel dapat dikatakan memiliki pengaruh apabila memiliki nilai $\mathrm{t}$ hitung $>$ nilai $\mathrm{t}$ tabel dan memiliki tingkat signifikan tinggi apabila memiliki nilai signifikan $<0,05$. Hasil perhitungan menunjukkan bahwa terdapat 1 variabel yang memiliki nilai t hitung > nilai t tabel, yaitu 5,754 > 2,056 dengan tingkat signifikan $0,001<0,05$. Sehingga dapat disimpulkan bahwa teknologi memiliki pengaruh yang berarti terhadap hubungan bisnis (lihat $\mathrm{t}$ hitung), artinya penggunaan teknologi memberikan dampak yang besar terhadap keberlangsungan hubungan bisnis. Variabel teknologi memberikan pengaruh terhadap hubungan bisnis dapat dilihat bahwa pemanfaatan teknologi saat ini bagi IKM sudah dirasa penting banyak IKM yang merasa bahwa marketplace dan sosial media sebagai sarana penting dalam meningkatkan hubungan bisnis kemudian pemanfaatan aplikasi dalam manajemen bisnis juga sudah diterapkan di beberapa IKM mulai dari pencatatan secara terkomputer walaupun masih bersifat sederhana.

Sedangkan variabel yang lain memiliki nilai $\mathrm{t}$ hitung $<\mathrm{t}$ tabel dan tingkat signifikan lebih besar dari 0,05 . Variabel sosial memiliki nilai t hitung 1,579 $<2,056$ dengan arah negatif dan tingkat signifikan >0,05. Pada variabel sosial ini ditemukan bahwa terdapat arah negatif di mana pengaruh negatif akan terjadi pada hubungan bisnis. Variabel budaya memiliki t hitung 0,428 $<2,056$ dengan arah positif dan tingkat signifikan $>0,05$. Pada variabel budaya ini ditemukan bahwa terdapat arah positif di mana pengaruh positif akan terjadi pada hubungan bisnis. Variabel waktu memiliki t hitung $0,429<2,056$ dengan arah negatif dan tingkat signifikan > 0,05. Pada variabel waktu ditemukan bahwa terdapat arah negatif di mana pengaruh negatif akan terjadi pada hubungan bisnis. Variabel geografis memiliki t hitung $0,941<2,056$ dengan arah positif dan tingkat signifikan $>0,05$. Pada variabel geografis ini ditemukan bahwa terdapat arah negatif di mana pengaruh negatif akan terjadi pada hubungan bisnis.

\section{Analisis Supply Chain Information}

Berdasarkan hasil wawancara kondisi lapangan di Disperinaker, terlihat bahwa belum adanya penggunaan suatu sistem informasi untuk mengelola Manajemen hubungan bisnis dan Supply Chain Information dengan IKM. Disperinaker sendiri telah menggunakan website dan sosial media sebagai sarana promosi dan memberikan informasi terkait kegiatan pelatihan, bantuan atau program lainnya, namun arus informasi tersebut masih bersifat satu arah dan belum bisa melakukan pertukaran 
informasi secara dinamis yaitu dua arah. Pada Disperinaker terdapat berbagai macam pelayanan yang diberikan kepada IKM antara lain sebagai berikut :

- Kegiatan Pelatihan: IKM yang telah terdaftar dan masuk ke dalam binaan Disperinaker dapat mengajukan usulan kegiatan pelatihan dengan cara membuat surat permohonan pelatihan yang dikirimkan ke Disperinaker. Surat permohonan kemudian ditinjau oleh bidang yang mengelola jenis IKM tersebut dengan mempertimbangkan anggaran serta beberapa pengajuan surat permohonan pelatihan yang telah masuk sebelumnya dan belum terealisasi. Apabila surat permohonan diterima, selanjutnya akan dikirimkan surat balasan perihal pelaksanaan kegiatan pelatihan. Selain itu juga dilakukan koordinasi terkait kegiatan yang akan dilaksanakan meliputi waktu, tempat, peserta pelatihan dan tindak lanjut terkait kesiapan kegiatan tersebut. Keluaran yang diharapkan dari kegiatan pelatihan tersebut adalah peningkatan keterampilan dari IKM. Selain fasilitas materi pelatihan, peserta juga diberi fasilitas tambahan berupa sertifikat, biaya transport dan akomodasi, serta alat produksi bagi industri tertentu (jika anggaran dan program memungkinkan). Berdasarkan data temuan lapangan dari hasil wawancara dengan Disperinaker dapat disimpulkan bahwa terdapat banyak arus informasi yang terjalin antara Disperinaker dan IKM. Secara visual, Gambar 5 menunjukkan arus informasi yang beredar antara Disperinaker dan IKM :

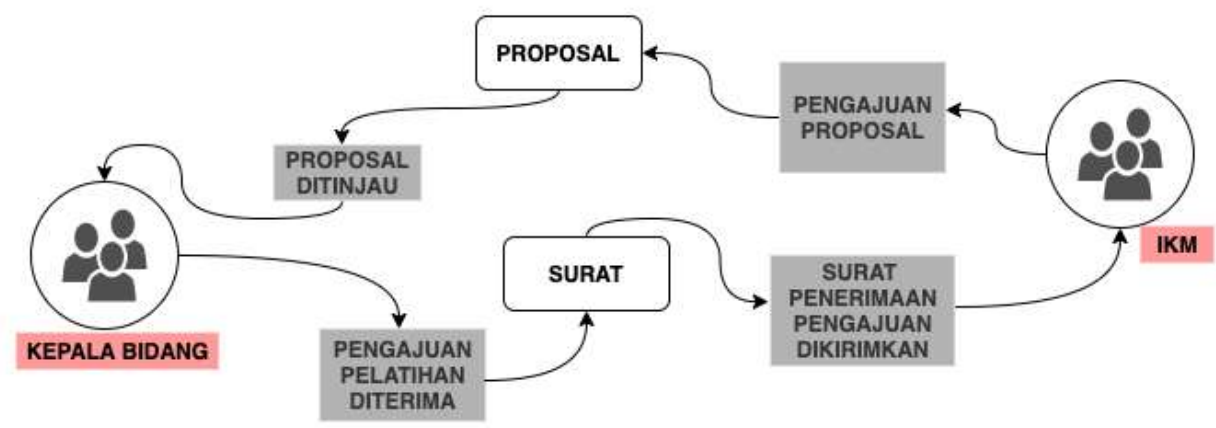

\section{Gambar 5. Arus informasi Kegiatan Pelatihan antara Disperinaker dan IKM}

- Fasilitas Ruang Pameran IKM: Disperinaker juga menyediakan sebuah tempat untuk menampilkan hasil atau karya yang telah diproduksi oleh IKM. Ruang pameran ini diperuntukkan apabila ada tamu atau masyarakat yang ingin melihat hasil produksi dari IKM, dengan tersedianya ruang pameran ini diharapkan hasil-hasil dari produksi IKM dapat dipromosikan dengan lebih mudah di tempat yang telah disediakan oleh Disperinaker. Pengajuan untuk menampilkan produk pada ruang pameran ini sendiri melalui beberapa proses seperti IKM menghubungi Kepala UPTD LIK (Lingkungan Industri Kecil) dengan membawa surat pengantar terkait penjelasan dari produk yang akan ditampilkan secara detail. Produk akan ditampilkan selama satu semester (6 bulan) kemudian produk yang ditampilkan akan diganti setiap semesternya. Apabila ada yang tertarik dan ingin membeli produk tersebut Disperinaker akan menghubungkan pembeli dengan IKM secara langsung, hal ini sejalan dengan tugas dari Disperinaker sebagai penghubung antara masyarakat dan IKM di mana Disperinaker tidak menerima pembelian langsung dari penjualan produk tersebut. Secara visual, Gambar 6 menunjukkan arus informasi pengajuan fasilitas ruang pameran IKM.

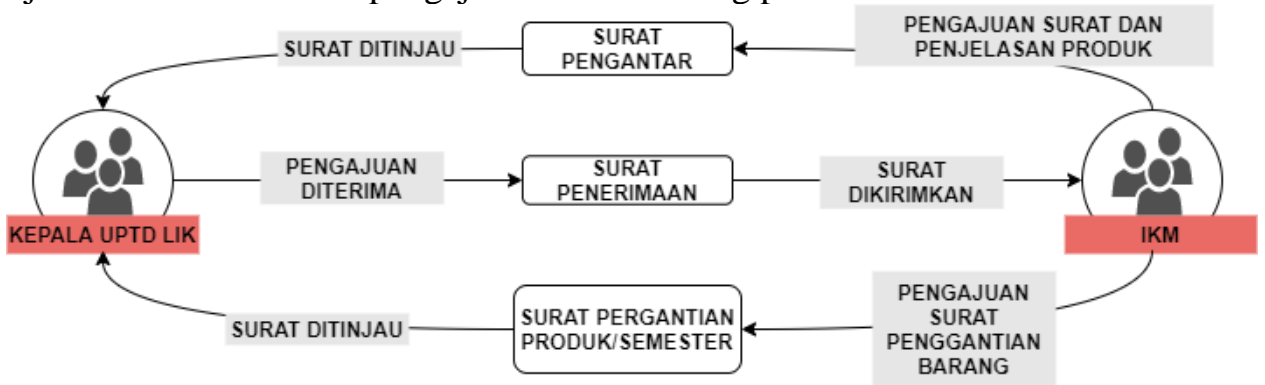

Gambar 6. Arus Informasi Pengajuan Fasilitas Ruang Pameran IKM 
- $\quad$ Kegiatan Pameran Expo: Pemerintah Daerah melalui Disperinaker memberikan informasi terkait pelaksanaan kegiatan pameran Expo kepada IKM dengan mengirimkan surat edaran, kemudian masing-masing IKM memberikan tanggapan terkait kesediaannya untuk mengikuti program tersebut, selanjutnya pihak Disperinaker akan mendata IKM yang bersedia, dan mempersiapkan kebutuhan yang diperlukan sesuai dengan kategori, ketika persiapan telah selesai Disperinaker akan mengirimkan surat berupa informasi teknis terkait persiapan pameran mulai dari lokasi booth, informasi bongkar muat serta waktu dan pelaksanaan. Secara visual, Gambar 7 menunjukkan arus informasi pelaksanaan kegiatan pameran expo.

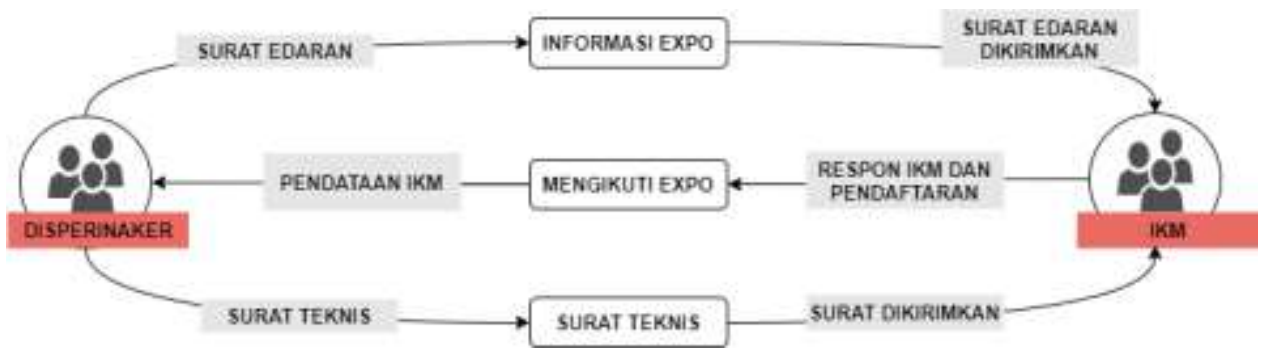

Gambar 7. Arus Informasi Pelaksanaan Kegiatan Pameran Expo

Supply Chain Information yang terjadi antara Disperinaker dan IKM di saat ini masih dilakukan secara konvensional, dampak berbagi informasi pada Supply Chain menjadi lebih signifikan dengan kemajuan terkini dalam Teknologi Informasi (TI) [19]. Dengan kemajuan teknologi informasi, struktur jaringan yang berbeda dapat dibuat model untuk membuat koordinasi dalam mitra Supply Chain semakin dekat. Kemitraan dan koordinasi ini mengarah pada Supply Chain yang lebih menguntungkan. Arus informasi akan meningkat, ketidakpastian dapat berkurang dan pelanggan akhir akan menerima produk atau layanan berkualitas lebih tinggi dengan biaya lebih rendah dalam periode waktu yang lebih singkat [29]. Secara umum diperlukan sebuah teknologi informasi agar Supply Chain Information ini dapat berjalan dengan efisien. Interaksi informasi antara Disperinaker dan IKM dapat berjalan dua arah. Pemanfaatan teknologi informasi ini dapat mengurangi kesalahan informasi, pengurangan biaya dan kecepatan arus informasi.

\section{Kesimpulan}

Pada penelitian ini hubungan bisnis antara Disperinaker dan IKM yang diukur berdasarkan variabel sosial, budaya, teknologi, waktu dan geografis ditemukan bahwa hanya variabel teknologi yang memberikan pengaruh berarti terhadap hubungan bisnis antara Disperinaker dan IKM di sedangkan variabel sosial, budaya, waktu dan geografis tidak memberikan pengaruh yang berarti terhadap hubungan bisnis antara Disperinaker dan IKM. Pengaruh variabel teknologi ini dapat dijadikan perhatian yang menyatakan bahwa pelaku usaha IKM telah menyadari bahwa penerapan Teknologi saat ini sangat penting. Kemudian untuk supply chain information antara Disperinaker dan IKM ditemukan bahwa pertukaran informasi cukup banyak terjadi antara kedua belah pihak mulai dari informasi terkait pengadaan pelatihan, pengajuan menampilkan produk di ruang pameran dan mengikuti kegiatan expo atau pameran yang diadakan. Pemanfaatan teknologi informasi dapat menjadi solusi dalam memberikan efisiensi, mengurangi kesalahan informasi, pengurangan biaya dan kecepatan arus informasi secara dua arah antar Disperinaker dan IKM.

\section{Referensi}

[1] C. Lindh, "Business Relationships and Integration of Information Technology," Malarden University, 2006.

[2] C. Harland, J. Telgen, G. Callender, R. Grimm, and A. Patrucco, "Implementing Government Policy In Supply Chains: An International Coproduction Study of Public Procurement," $J$. Supply Chain Manag., Vol. 55, No. 2, pp. 6-25, 2019.

[3] A. Verma and N. Seth, "A Conceptual Framework for Supply Chain Competitiveness," World Acad. Sci. Eng. Technol., Vol. 81, No. January 2011, pp. 903-908, 2011.

[4] P. Ekman, "Enterprise System and Business Relationship," Malardalen University, Sweden, 
2006.

[5] L. Bagdoniene and R. Zilione, "Business to Business Relationships: The Variables In The Context Of Success," Soc. Sci., Vol. 4, No. 66, pp. 16-25, 2009.

[6] A. Waylen, "The Importance of Communication In Dentistry," Dent. Update, Vol. 44, No. 8, pp. 774-780, 2017.

[7] L. Schmeltz, "Identical or Just Compatible? The Utility of Corporate Identity Values In Communicating Corporate Social Responsibility," J. Bus. Commun., Vol. 51, No. 3, pp. 234258, 2014.

[8] W. . Arrindell, "Culture's Consequences: Comparing Values, Behaviors, Institutions, and Organizations Across Nations," Behav. Res. Ther., Vol. 41, No. 7, pp. 861-862, 2003.

[9] I. Geiger and M. Kleinaltenkamp, Instruments of Business Relationship Management, No. January. 2015.

[10] C. J. Medlin, "Interaction In Business Relationships: A Time Perspective," Ind. Mark. Manag., Vol. 33, No. 3, pp. 185-193, 2004.

[11] M. Johanson, "the Impact of Geographical Proximity and Technology on Firms ' R \& DOperations," Business, No. Wilson 1995, pp. 1-12, 2005.

[12] C. Arysta, P. Pradana, and T. Domai, "Peran Dinas Perindustrian dan Perdagangan Dalam Pemberdayaan Pengrajin Kerajinan Perak Sebagai Produk Unggulan Daerah," J. Adm. Publik, No. 1, pp. 95-101, 2012.

[13] H. Asy'ari, "Peranan Disperindagkop \& Ukm Dalam Mempromosikan Produk Ikm Di Yogyakarta," 2015.

[14] A. F. Fadirianto and M. S. Hakam, "Peranan Pemerintah Daerah Dalam Pembinaan dan Pengembangan Industri Kecil Menengah,” J. Adm. Bisnis, Vol. 58, No. 1, pp. 147-155, 2018.

[15] V. Albino, N. Carbonara, and I. Giannoccaro, "Supply Chain Management Models For Industrial Districts: An Agent-Based Simulation Study," Int. J. Intell. Syst. Technol. Appl., Vol. 6, No. 3-4, pp. 332-348, 2009.

[16] I. Giannoccaro and P. Pontrandolfo, "Inventory Management In Supply Chains: A Reinforcement Learning Approach,” Int. J. Prod. Econ., Vol. 78, No. 2, pp. 153-161, 2002.

[17] Michael Maloni and W. C. Benton, "Power Influences In The Supply Chain," J. Bus. Logist., Vol. 21, No. 1, pp. 49-74, 2000.

[18] P. D. Larson, P. Carr, and K. S. Dhariwal, "Scm Involving Small Versus Large Suppliers: Relational Exchange and Electronic Communication Media," J. Supply Chain Manag., Vol. 41, No. 1, pp. 18-29, 2005.

[19] Z. Lotfi, M. Mukhtar, S. Sahran, and A. T. Zadeh, "Information Sharing In Supply Chain Management," Procedia Technol., Vol. 11, No. Iceei, pp. 298-304, 2013.

[20] G. Kong, S. Rajagopalan, and H. Zhang, "Revenue Sharing and Information Leakage In A Supply Chain," Manage. Sci., Vol. 59, No. 3, pp. 556-572, 2013.

[21] D. Ariani and B. M. Dwiyanto, "Analisis Pengaruh Supply Chain Management Terhadap Kinerja Perusahaan (Studi Pada Industri Kecil dan Menengah Makanan Olahan Khas Padang Sumatera Barat)," J. Stud. Manaj. Organ., Vol. 10, No. 2, pp. 132-141, 2013.

[22] A. Vafaei-Zadeh, T. Ramayah, H. Hanifah, S. Kurnia, and I. Mahmud, "Supply chain information integration and its impact on the operational performance of manufacturing firms in Malaysia," Inf. Manag., vol. 57, no. 8, p. 103386, 2020.

[23] J. W. Creswell, Research Design: Qualitative, Quantitative, and Mixed Methods Approaches. SAGE Publications, 2014.

[24] G. Guest and P. Fleming, "Mixed Methods Research," 2015, pp. 581-610.

[25] P. Sugiyono, Metode penelitian kombinasi (mixed methods). 2015.

[26] P. Sugiyono, "Metodologi penelitian kuantitatif kualitatif dan R\&D," Alpabeta, Bandung, 2011.

[27] X. Yan, Linear Regression Analysis: Theory and Computing. World Scientific Publishing Company Pte Limited, 2009.

[28] R. Olkkonen, H. Tikkanen, and K. Alajoutsijärvi, "The role of communication in business relationships and networks," Manag. Decis., vol. 38, no. 6, pp. 403-409, 2000.

[29] P. Fiala, "Information sharing in supply chains," Omega, vol. 33, no. 5, pp. 419-423, 2005. 